\title{
PENGARUH KADAR AIR TERHADAP NILAI WARNA CIE PADA GULA SEMUT
}

\section{EFFECT OF MOISTURE CONTENT ON CIE COLOR VALUES IN GRANULATED PALM SUGAR}

\author{
Hary Kurniawan \\ Program Studi Teknik Pertanian, Universitas Mataram \\ Komunikasi Penulis, email: harykurniawan@unram.ac.id \\ DOI:http://dx.doi.org/10.23960/jtep-lv9i3.213-221 \\ Naskah ini diterima pada 24 Juli 2020; revisi pada 25 Agustus 2020; \\ disetujui untuk dipublikasikan pada 8 September 2020
}

\begin{abstract}
Colour is one of the essential attributes as product quality criteria that determine the acceptance of a product by consumers. Granulated palm sugar is a crystalline form, which is hygroscopic. The purpose of this study was to study the colour changes through the CIELab ( $L, a$ and $b)$ colour system to the changes in the moisture content of granulated palm sugar during storage. Changes in the values of $L$, a and $b$ were observed during storage at $300 C$ and $76 \% R H$. The results showed that the moisture content of granulated palm sugar increased from $3.84 \% \mathrm{wb}$ to $8.40 \% \mathrm{wb}$ for 10 hours of storage. The $L$ value tends to decrease with an increasing water content which causes it to turn dark brown. While the cost of a tends to increase with increasing moisture content, the colour of the granulated palm sugar to reddish. The same thing happened to the value of $b$, which increases with the moisture content of granulated palm sugar and causes it tends to yellowish. Thus, the change in ant sugar moisture content gives a significant difference to the $L$, a and $b$ values during storage.
\end{abstract}

Keywords: colour, moisture content, palm sugar

\begin{abstract}
ABSTRAK
Warna menjadi salah satu atribut penting sebagai kriteria kualitas produk yang menentukan penerimaan suatu produk oleh konsumen. Gula semut merupakan gula aren berbentuk butiran atau kristal yang bersifat higroskopis. Tujuan penelitian ini adalah mempelajari perubahan warna melaui sistem warna CIELab (L, a dan b) terhadap perubahan kadar air gula semut selama penyimpan. Perubahan nilai $\mathrm{L}$, a dan b diamati pada gula semut selama penyimpanan pada suhu $30^{\circ} \mathrm{C}$ dan $\mathrm{RH} 76 \%$. Hasil menunjukkan bahwa kadar air gula semut meningkat dari $3,84 \%$ wb menjadi 8,40\% wb selama 10 jam penyimpanan. Nilai L cenderung menurun dengan meningkatnya kadar air yang menyebabkan gula semut berwarna kearah coklat gelap. Sementara nilai a cenderung meningkat seiring kenaikan kadar air, dengan warna gula semut cenderung kemerahan. Hal serupa juga terjadi pada nilai b yang meningkat seiring kenaikan kadar air dan menyebabkan gula semut cenderung kekuningan. Dengan demikian perubahan kadar air gula semut memberikan perubahan berarti terhadap nilai L, a dan b selama penyimpanan.
\end{abstract}

Kata kunci: gula semut, kadar air, warna

\section{PENDAHULUAN}

Gula semut merupakan salah satu diversifikasi produk gula palma yang berbentuk butiran atau serbuk yang berasal dari dari nira aren, nira kelapa atau nira siwalan. Proses pembuatan gula semut hampir sama dengan pembuatan gula cetak, yaitu dengan memasak nira hingga mengental, lalu didinginkan dan diaduk hingga terbentuk butiran atau kristal. Gula semut memiliki beberapa keunggulan dibandingkan gula cetak antara lain lebih awet karena kadar airnya rendah, karena berbentuk kristal maka penggunaannya lebih praktis, mudah dalam pengemasan, pengangkutan, dan harganya pun lebih tinggi (Amanah et al., 2013; Fahrizal, et al., 2017; Kurniawan et al., 2018;).

Warna merupakan salah satu atribut kualitas penting pada produk pangan. Meskipun tidak 
mencerminkan nilai gizi, rasa, atau fungsional, atribut warna menentukan penerimaan suatu produk oleh konsumen. Atribut warna suatu produk sangat penting bagi konsumen sebagai kriteria kualitas produk, karena konsumen mengaitkannya dengan kesegaran dan sangat penting dalam penerimaan produk tertentu. Warna makanan diatur oleh perubahan kimia, biokimia, mikroba, dan fisik yang terjadi selama pertumbuhan, pematangan, penanganan dan pemrosesan pascapanen. Pengukuran warna produk makanan telah digunakan sebagai ukuran tidak langsung dari atribut kualitas lainnya seperti rasa dan isi pigmen karena lebih sederhana, lebih cepat dan berkorelasi baik dengan sifat fisikokimia lainnya. Warna diartikan sebagai fenomena persepsi yang tergantung pada pengamat dan kondisi di mana warna diamati. Ketika suatu objek dinilai secara visual; tiga faktor fisik harus ada. Harus ada sumber cahaya, objek, dan mekanisme reseptor cahaya. Ini adalah karakteristik cahaya, yang dapat diukur dari segi intensitas dan panjang gelombang. Warna material menjadi terlihat hanya ketika cahaya dari objek atau sumber yang bercahaya menerangi atau menghantam permukaan (Sahin \& Sumnu, 2006; Vidal et al., 201; Kortei et al., 2015; Saricoban \& Yilmaz, 2010; Pathare et al., 2013).

Warna didefinisikan sebagai dampak dari panjang gelombang cahaya dalam spektrum yang terlihat (390-760 nm) yang dapat dideteksi oleh mata manusia dan merupakan salah satu atribut utama yang sangat terkait dengan konsep kualitas. Warna adalah atribut kualitas yang sangat penting dari makanan mentah dan olahan. Warna memiliki dampak signifikan pada persepsi konsumen tentang kualitas dan mempengaruhi konsumen pada faktor kualitas penting lainnya, seperti rasa dan aroma. Selain penerimaan konsumen, warna juga digunakan untuk kontrol proses. Oleh karena itu pengukuran warna sangat berharga dalam memperkirakan degradasi warna, sehingga memprediksi perubahan kimia dan kualitas makanan. (Wibowo et al., 2015, Salehi \& Kashaninejad, 2018)

Telah dilaporkan bahwa banyak reaksi dapat mempengaruhi warna selama pemrosesan, diantaranya yang paling umum adalah degradasi pigmen, terutama karotenoid dan klorofil, dan reaksi kecoklatan seperti kondensasi hexoses dan komponen amino Maillard, dan oksidasi asam askorbat. Faktor-faktor lain yang mempengaruhi warna termasuk $\mathrm{pH}$ buah, keasaman, suhu dan lamanya pemrosesan, kultivar dan ada tidaknya kontaminasi logam berat. Untuk meminimalkan kerusakan warna, desain yang sesuai diperlukan untuk pembuatan dan peralatan perawatan. Dan juga, beberapa proses gabungan seperti suhu-tekanan hidrostatik tinggi telah digunakan untuk retensi warna buah dan produk buah (Maskan, 2001).

Pengukuran warna dapat digunakan secara tidak langsung untuk memperkirakan perubahan warna produk pangan karena lebih sederhana dan lebih cepat daripada analisis kimia. Parameter warna $(\mathrm{L}, \mathrm{a}, \mathrm{b})$ sebelumnya terbukti membantu dalam menggambarkan penurunan warna visual dan memberikan informasi yang berguna untuk kontrol kualitas. Colourimeter menghasilkan tiga parameter $\mathrm{L}^{*}, \mathrm{a}^{*}, \mathrm{~b}^{*}$. Ini digunakan secara luas di banyak industri di seluruh dunia yang kadang-kadang disebut sebagai metrik perbedaan warna CIELAB. (Maskan, 2001; Kortei et al., 2015)

Meskipun warna dapat dievaluasi melalui analisis visual, penting untuk menentukan warna secara objektif, karena penilaian visual bersifat subyektif dan dapat menjadi bias. Selain itu, pengukuran warna sangat berharga dalam memperkirakan degradasi warna, sehingga memprediksi perubahan kimia dan kualitas makanan. Sejumlah penelitian telah dilaporkan diantaranya pengaruh kadar air terhadap perubahan warna pada bubuk paprika oleh Horváth \& Hodúr (2006) diman kenaikan kadar air pada bubuk paprika telah mengakibatkan perubahan yang signifikan terhadap penurunan nilai L, chroma maupun derajat hue. Addala et al. (2015) juga melaporkan pengaruh kondisi dan lama penyimpanan terhadap laju degradasi warna paprika dan bubuk paprika. Dilaporkan bahwa terjadi degradasi warna yang siginifikan pada kedua kategori produk tersebut selama penyimpanan. Selain itu juga terdapat korelasi positif antara kadar air dan aktivitas air terhadap extractabel color (ASTA) dan derajat hue baik pada penyimpanan suhu ruang maupuan pada penyimpanan suhu tinggi. Sementara Sementara 
Ozkan et al. (2003) menginvestigasi perubahan warna apricot kering pada berbagai variasi kadar air. Dilaporkan bahwa terdapat hubungan linier antara variable warna $\left(\mathrm{L}^{*}, \mathrm{a}^{*}, \mathrm{~b}^{*}\right)$ terhadap kadar air apricot kering yang direhidrasi pada level kadar air 15,49\% - 30,20\%. Penelitian ini bertujuan untuk mempelajari perubahan warna gula semut terhadap perubahan kadar air selama penyimpanan berdasarkan nilai warna CIE (L, a dan b). Perubahan warna selama penyimpanan diamati secara visual dan ditandai melalui ruang warna CIELAB.

\section{BAHAN DAN METODA}

Bahan yang digunakan adalah gula semut yang diperoleh dari pengrajin gula aren di Desa Kekait, Kecamatan Gunung Sari, Kabupaten Lombok Barat. Sementara itu alat yang digunakan antara lain oven (Memmert Model UNB 400), color reader (MiniScan EZ, Hunter Lab), kamera (Samsung Galaxy A7 2018), penjepit, termostatik cabinet (Lovibond model ET 618-4), termohigrometer (Lutron, AM-4247SD), mini studio box, cawan plastik, kertas label, cawan aluminium dan kuas.

Gula semut dikeringkan menggunakan oven pada suhu $70^{\circ} \mathrm{C}$ selama $1 \mathrm{jam}$. Setelah itu diayak menggunakan ayakan dengan mesh 20 , lalu diukur kadar air awalnya menggunakan metode oven dan diukur parameter warnanya menggunakan color reader. Selanjutnya sebanyak 10 gram gula semut di tuang dan diratakan pada wadah plastik berwarna putih. Perlakuan ini dilakukan hingga diperoleh 20 sampel. Keduapuluh sampel tersebut disimpan dalam termostatik kabinet yang suhu dan $\mathrm{RH}-$ nya dijaga konstan sebesar $30^{\circ} \mathrm{C}$ dan $76 \%$. Lalu setiap 30 menit diambil satu sampel, difoto dan diukur parameter warna (L, a, b) menggunakan MiniScan EZ dari Hunter Lab, setelah itu diukur kadar airnya menggunakan metode oven.

Penentuan kadar air gula semut dilakukan menggunakan metode oven mengacu pada AOAC 1995 pada suhu $105^{\circ} \mathrm{C}$ sampai diperoleh berat konstan. Sementara nilai warna dinyatakan sebagai L (whiteness atau brightness/darkness), a (redness/greenness) and b (yellowness/ blueness) yang diukur setiap waktu, berturutturut.

\section{HASIL DAN PEMBAHASAN}

\subsection{Perubahan Kadar Air Selama Penyimpanan}

Gula semut yang digunakan terlebih dahulu dikeringkan menggunakan oven pada suhu $70^{\circ} \mathrm{C}$ selama 1 jam dan diperoleh kadar air awal sebesar 3,84\% wb dengan nilai awal atribut $\mathrm{L}=$ $62,03, a=13,82$ dan $b=41,32$. Gambar 1 menunjukkan perubahan kadar air gula semut yang disimpan selama 10 jam pada suhu $\pm 30^{\circ} \mathrm{C}$ dan $\mathrm{RH} \pm 76 \%$ dimana terjadi kenaikan kadar air gula semut yang signifikan setiap interval pengamatan selama 30 menit, dan dicapai kadar air sebesar $8,40 \%$ pada akhir pengamatan. Hasil pengukuran menunjukkan bahwa pada penyimpanan selama 30 menit, kadar air gula semut meningkat sebesar 5,38\% yang telah melampaui batas maksimum dari kadar air yang ditetapkan dalam SNI Gula Palma. Peningkatan kadar air gula semut menunjukkan bahwa gula semut bersifat higroskopis, yang artinya mudah menyerap uap air dari lingkungannya. Sifat higroskopis ini disebabkan adanya gula pereduksi yang mempunyai gugus hidroksil, akibatnya gula semut mudah menyerap uap air dari udara sekitar dan menyebabkan kadar air gula semut meningkat selama penyimpanan dan gula semut menjadi tidak tahan lama (Mustaufik dan Haryanti, 2006; Wibisono, 2017). Pontoh (2013) melaporkan bahwa gula pereduksi pada gula semut yaitu sekitar 2,0-2,4\%. Semakin rendah gula pereduksi maka kecenderungan gula aren untuk menyerap air semakin rendah dan semakin bagus kualitas gula tersebut. Kadar gula pereduksi pada gula semut dapat mempengaruhi kekerasan, warna dan rasa gula (Muchaymien et al., 2014; Dewi, 2018). Selain itu, Chung et al. (2000) melaporkan bahwa tingginya kadar air pada produk dapat menurunkan flowability, dan meningkatkan kohesivitas glanural sehingga mempercepat terjadinya penggumpalan. Adanya penggumpalan pada poduk berbentuk serbuk adalah tanda kualitas dan keamanan produk rendah.

\subsection{Perubahan nilai $L$, a dan b Selama Penyimpanan}

Warna merupakan salah satu atribut kualitas yang sangat penting dari suatu produk pangan karena warna dianggap memiliki dampak yang signifikan pada persepsi konsumen terhadap 


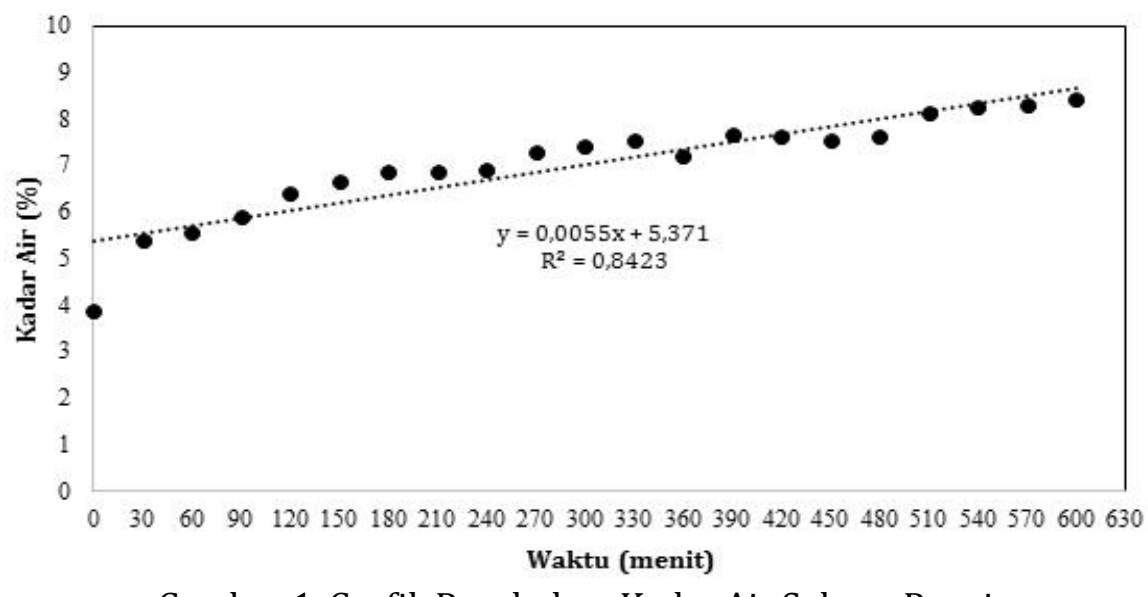

Gambar 1. Grafik Perubahan Kadar Air Selama Penyimpanan

kualitas dan bahkan mempengaruhi konsumen pada faktor kualitas penting lainnya, seperti rasa dan aroma. Meskipun warna dapat dievaluasi melalui analisis visual, namun penting untuk menentukan warna secara objektif, karena penilaian visual bersifat subyektif dan dapat menjadi bias. Dalam penelitian ini, perubahan warna selama penyimpanan diamati secara visual dan ditandai melalui ruang warna CIELAB. Sistem warna CIELab digunakan untuk karakterisasi warna. Dalam ruang warna tersebut, titik warna ditandai dengan tiga koordinat yaitu L adalah koordinat cahaya mulai dari tidak ada refleksi untuk hitam $(\mathrm{L}=0)$ hingga pantulan sempurna untuk putih $(\mathrm{L}=100)$. Koordinat a adalah koordinat kemerahan mulai dari nilai negatif untuk hijau hingga nilai positif untuk merah. Sedangkan koordinat b adalah koordinat kekuningan mulai dari nilai negatif untuk biru dan nilai positif untuk kuning.

Perubahan warna gula semut selama 10 jam penyimpanan ditentukan melalui nilai koordinat $\mathrm{L}$, a dan b seperti yang ditunjukkan pada Gambar 2. Nilai L gula semut menurun signifikan seiring perubahan waktu, yang artinya cenderung berkurang tingkat kecerahannya atau dengan kata lain cenderung menuju gelap seperti ditunjukkan pada Gambar 2a. Penurunan nilai L rata-rata sebesar 0.46 unit dan penurunan terjadi secara drastis setelah 60 menit penyimpanan. Secara umum, penurunan L tidak diinginkan karena itu berarti produk menjadi lebih gelap, yang tidak dapat diterima untuk produk gula semut. Nilai L yang rendah menunjukkan warna gelap dan terutama terkait dengan reaksi kecoklatan non-enzimatik. Timbulnya warna kecoklatan biasanya dikaitkan dengan reaksi mailard yang didasarkan pada pembentukan senyawa ammonia bebas yang terbentuk dari degradasi asam amino yang memicu terbentuknya warna coklat sehingga menurunkan nilai L (Victor dan Orsat, 2018; Salehi dan Kashaninejad, 2018; Ho et al., 2008). Özkan et al., (2003) melaporkan hasil penelitiannya pada apricot kering menunjukkan bahwa panjang gelombang cahaya yang dipantulkan dari aprikot berubah sebagai akibat dari rehidrasi (perubahan kadar air). Selama rehidrasi aprikot kering berlangsung, air memasuki ruang udara di antara jaringan dan mengubah panjang gelombang cahaya yang dipantulkan dari permukaan apricot sehingga terjadi perubahan nilai warna L, a dan b. Selain itu gula semut dihasilkan dari proses pemasakan nira aren yang erat kaitannya dengan derajat intensitas warna yang dipicu adanya keberadaan gula pada nira aren baik dalam bentuk mono, oligo maupun polisakarida dana serta interaksi dengan kelompok asam amino (Ho et al., 2008) Pada Gambar 2b dan 2c, nilai koordinat a dan b meningkat signifikan selama 10 jam penyimpanan dengan nilai positif yang berarti cenderung ke merah (redness) dan cenderung ke arah kuning (yellowness) berturut-turut Ratarata perubahan koordinat a dan b masing-masing sebesar 0,13 unit dan 0,27 unit Nilai L dan b pada gula semut lebih dominan yang ditandai kedua nilai yang lebih besar dibanding nilai a dimana hal serupa dilaporkan oleh Victor dan Orsat (2018), dimana menunjukkan bahwa a memiliki perubahan yang kurang signifikan daripada $b$, dan L yang paling banyak berubah di antara nilai ruang warna ini. Tren menurunnya nilai $L$ dan 
meningkatnya nilai a dan b secara konsisten dilaporkan oleh Rao et al. (2009), Maskan et al. (2002) dan Victor dan Orsat (2018).

\subsection{Pengaruh Kadar Air terhadap Ruang Warna $L$, a dan b}

Warna selain mempengaruhi penerimaan konsumen, juga digunakan sebagai kontrol proses. Oleh karena itu pengukuran warna sangat berharga dalam memperkirakan degradasi warna, sehingga memprediksi perubahan kimia dan kualitas produk pangan (Pathare et al., 2013; Wibowo et al., 2015, Salehi \& Kashaninejad, 2018). Gambar 3 menunjukkan perubahan warna gula semut pada berbagai kondisi kadar air. Özkan et al. (2003) melaporkan bahwa kadar air sangat mempengaruhi nilai warna pantulan produk. Horváth, (2016) juga melaporkan bahwa warna pada produk powder dipengaruhi oleh banyak faktor seperti ukuran partikelnya, kandungan minyak dan kandungan air, serta kandungan agen warna. Selain itu kenaikan kadar air suatu produk powder juga diketahui menyebabkan produk seperti halnya gula semut mengalami penggumpalan (caking). Chung et al. (2000) menyatakan penggumpalan sering menyebabkan perubahan kelarutan, peningkatan oksidasi lipid dan aktivitas enzimatik, hilangnya rasa dan kerenyahan, serta penurunan kualitas organoleptik dan umur simpan. Bahkan penggumpalan pada produk
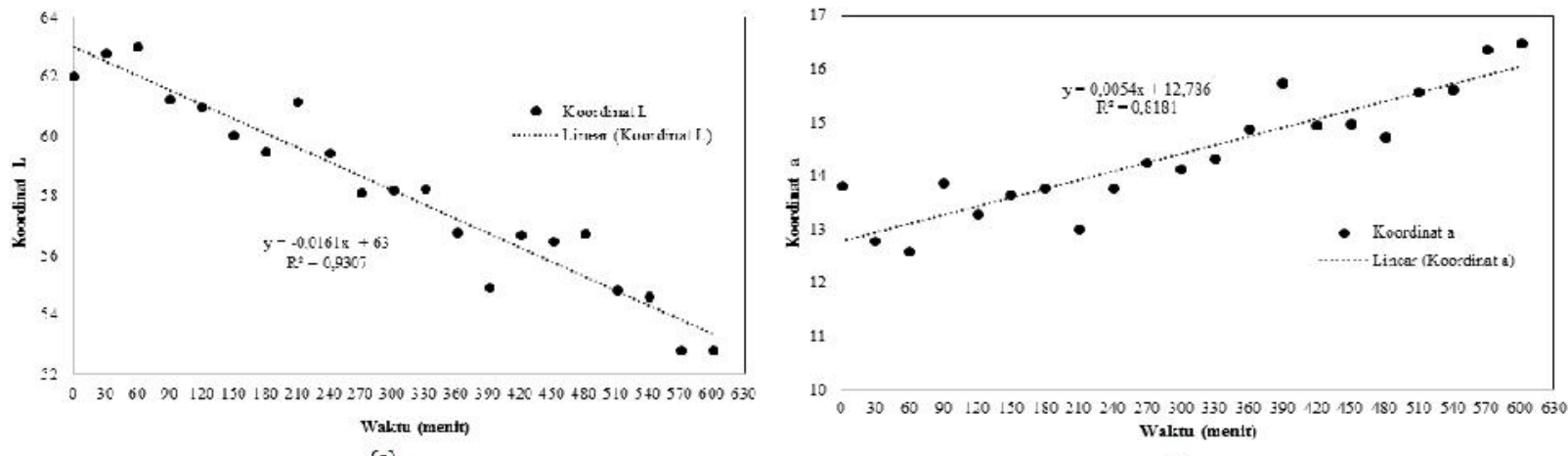

(a]

(b)

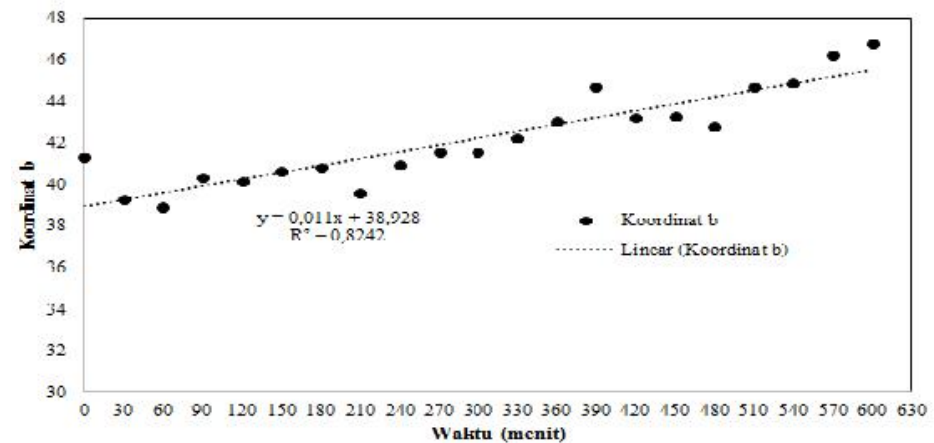

(c)

Gambar 2. Perubahan Ruang Warna L, a dan b Selama Penyimpanan

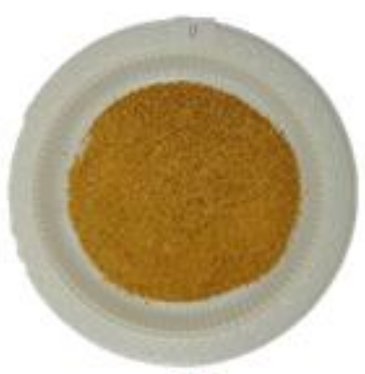

(a)

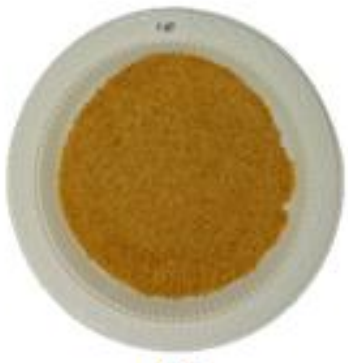

(b)

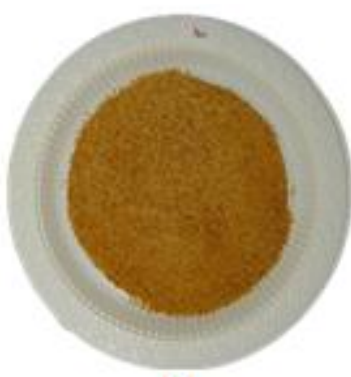

(c)

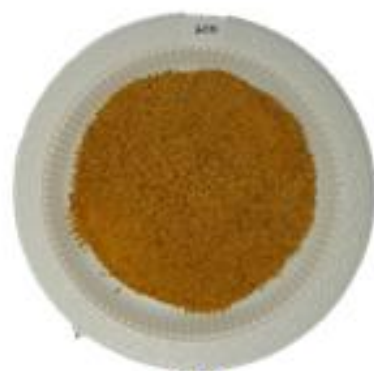

(d)

Gambar 3. Warna Gula Semut Selama Penyimpanan Pada Kadar Air (a) 3,87\%, (b) 6,87\%, (c) $7,20 \%$, dan (d) $8,40 \%$ 


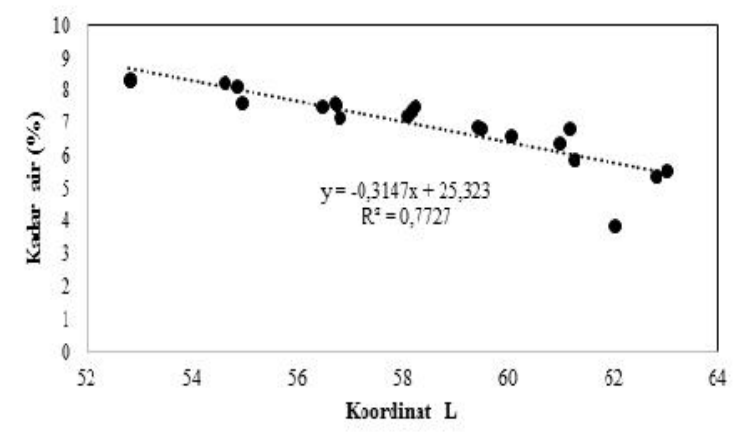

(a)

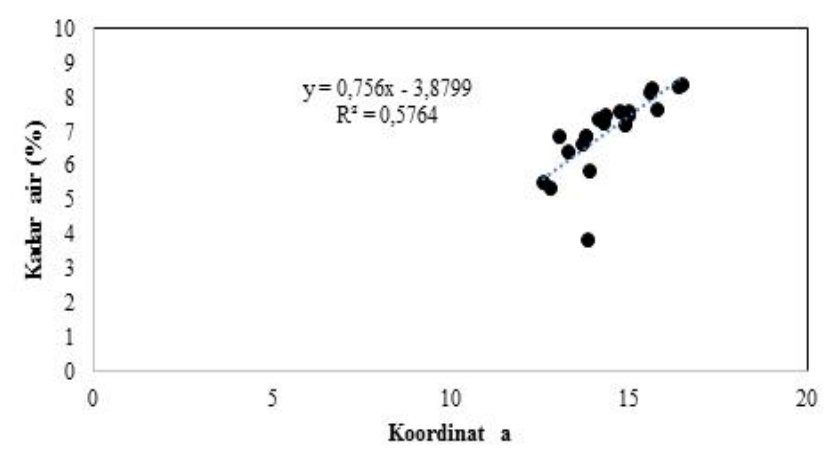

(b)

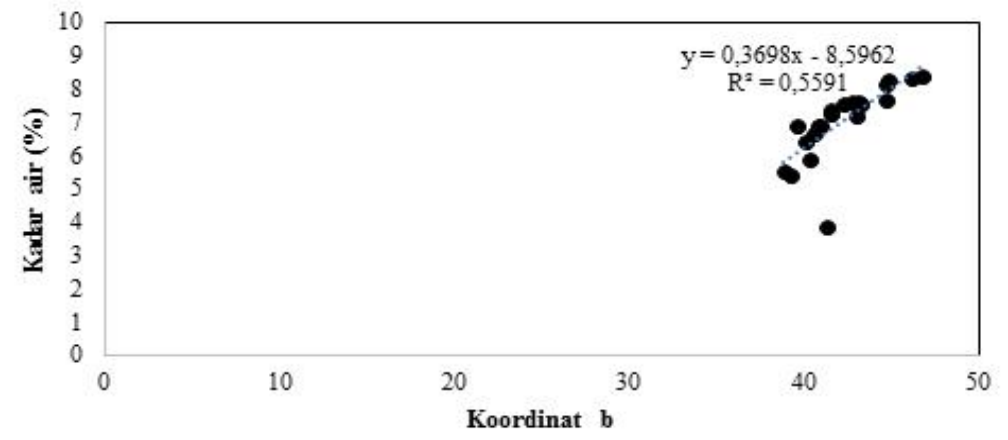

(c)

Gambar 4. Hubungan Kadar Air Terhadap Ruang Warna L, a, dan b

powder merupakan tanda kualitas dan keamanan yang buruk.

Berdasarkan Gambar 4a, dapat dilihat bahwa koordinat L cenderung menurun dengan meningkatnya kadar air. Hal ini menunjukkan bahwa kenaikan kadar air gula semut menyebabkan gula semut cenderung kearah coklat gelap. Nilai L pada awal penyimpanan adalah sebesar 62,03, dengan kadar air sebesar $3,87 \%$, kemudian setelah 10 jam penyimpanan atau pada akhir pengamatan diperoleh nilai $\mathrm{L}$ sebesar 52,80 dengan kadar air akhir gula semut sebesar $8,40 \%$. Semakin gelap produk maka nilai L semakin rendah begitupun sebaliknya. Dewi (2018) melaporkan bahwa Reaksi pencoklatan yang terjadi pada gula semut aren merupakan reaksi pencoklatan non enzimatis yaitu reaksi maillard. Reaksi maillard merupakan reaksi yang diawali dengan kondensasi grup karbonil dengan grup amino bebas dari asam amino, peptide atau protein dengan menghasilkan produk akhir pigmen cokelat yang dinamakan melanoidin. Nilasari et al., (2017) melaporkan bahwa rekasi mailard dipengaruhi oleh suhu. Sementara Ho et al. (2008) melaporkan bahwa reaksi mailard dipengaruhi kadar air yang diketahui memainkan peran penting pada berbagai tahap reaksi mailard. Selain ituPada gambar $4 \mathrm{~b}$ dan $4 \mathrm{c}$ menunjukkan bahwa nilai a dan b meningkat signifikan seiring dengan kenaikan kadar air. Nilai a adalah koordinat kromatis yang menunjukkan kemerahan atau kehijauan pada sampel. Nilai a positif menunjukkan kemerahan sampel sedangkan nilai a negatif menunjukkan kehijauan sampel. Pada Gambar 4b, nilai a cenderung meningkat seiring kenaikan kadar air, dimana pada akhir pengamatan nilai a sebesar 16,49 , yang menunjukkan bahwa gula semut cenderung kemerahan seiring kenaikan kadar air. Hal serupa juga terjadi pada nilai b, dimana nilai b positif menunjukkan kekuningan sampel sedangkan nilai b negatif menunjukkan kebiruan sampel. Gambar 4c menunjukkan nilai b cenderung meningkat seiring kenaikan kadar air, dimana nilai $b$ diakhir pengamatan sebesar 46,78 . Hal ini menunjukkan bahwa gula semut cenderung kekuningan seiring kenaikan kadaa air. Dengan demikian hal ini sesuai dengan yang dilaporkan oleh Horváth \& Hodúr (2007) bahwa koordiat $\mathrm{L}$, a dan b secara signifikan dipengaruhi oleh kadar air.

Perubahan kadar air gula semut terhadap nilai L, a dan b selama penyimpanan juga dinyatakan dalam persamaaan regresi linier dan nilai 
koefisien determinasi $\left(\mathrm{R}^{2}\right)$. Koefisien determinasi menjelaskan variasi pengaruh variabel-variabel bebas terhadap variabel terikatnya. Apabila dilihat dari nilai R-square sebesar 0,7727 menunjukkan bahwa proporsi pengaruh nilai $\mathrm{L}$ terhadap kadar air gula semut sebesar 77,27\%, yang berarti kecerahan yang dinyatakan sebagai nilai L memiliki proporsi pengaruh terhadap kadar ar gula semut sebesar $77,27 \%$, sedangkan sisanya $22,73 \%$ dipengaruhi oleh faktor lain. Demikian halnya untuk nilai a dan b, dimana nilai R-squarenya masing-masing sebesar 0,5764 dan 0,5591 , yang berarti pengaruh perubahan kadar air gula smeut terhadap nilai a dan b masingmasing sebesar $57,64 \%$ dan $55,91 \%$, sedangkan sisanya masing-masing dipangaruhi faktor lain. Nilai R-square yang kecil diduga nilai $a$ dan $b$ kurang memberikan sedikit pengaruh yang signifikan terhadap perubahan kadar air. Diketahui nilai a yang semakin positif mengakibatkan warna objaek akan cenderung kemerahan, sedangkan nilai a yang semakin negatif akan mengarah kehijauan. Sementara nilai b yang semakin positif akan mengarah ke kekuningan dan nilai b yang semakin negative akan menuju ke biruan.

Hasil analisis korelasi menunjukkan adanya korelasi antara kkadar air dengan nilai L yaitu sebesar -0,8790. Nilai tersebut menunjukkan adanya korelasi yang signifikan, negatif, dan sangat kuat. Artinya semakin rendah nilai L atau semakin berkurang kecerahannya maka kadar air gula semut semakin tinggi. Sementara korelasi antara kadar air dengan nilai a dan b menunjukkan korelasi yang signifikan, positif dan kuat yaitu masing-masing sebesar 0,7591 dan 0,7477 . Artinya semakin tinggi kadar air gula semut, maka nilai a dan b semakin tinggi, yang berarti gula semut akan cenderung kemerahan dan kekuningan.

\section{KESIMPULAN}

Kadar air gula semut meningkat seiring lama penyimpanan pada suhu $30^{\circ} \mathrm{C}$ dan $\mathrm{RH} 76 \%$. Nilai L cenderung menurun dengan meningkatnya kadar air yang menyebabkan gula semut menyebabkan gula semut cenderung kearah coklat gelap. Sementara nilai a cenderung meningkat seiring kenaikan kadar air, dengan warna gula semut cenderung kemerahan. Hal serupa juga terjadi pada nilai b yang meningkat seiring kenaikan kadar air dan menyebabkan gula semut cenderung kekuningan. Dengan demikian perubahan kadar air gula semut memberikan perubahan berarti terhadap nilai $\mathrm{L}$, a dan b selama penyimpanan.

\section{DAFTAR PUSTAKA}

Amanah, H.Z.T, Erlinda, Rahayoe, S., Setyowati, P. 2013. Analisis Kinerja Alat Pengering Tipe Rak (Cabinet Dryer) untuk Pengeringan Gula Semut. Seminar Nasional Sains \& Teknologi, Lembaga Penelitian Universitas Lampung, 19-20 November 2013: 1260-1268.

Chung, M. S., Ruan, R.R., Chen, P., Chung, S.H., Ahn, T.H., Lee, K.H. 2000. Study of Caking in Powdered Foods Using Nuclear Magnetic Resonance Spectroscopy. Journal of Food Science, 65 (1), 134-138.

Dewi, A.R. 2018. Pendugaan Umur Simpan Gula Semut Aren Dengan Metode Arrhenius. Skripsi. Fakultas Teknologi Pertanian Institut Pertanian Bogor. Bogor

Fahrizal, Nggandung, Y., Kartiwan. Optimasi Produksi Gula Cetak dan Gula Semut Lontar Terintegrasi Dengan Metode Linear Programming. Seminar Nasional Hasil Penelitian (SNHP)-Vii Lembaga Penelitian dan Pengabdian Kepada Masyarakat Universitas PGRI Semarang. 2017: 505 - 510.

Horváth, Zs. H. 2016. The effect of storage on the colour of paprika powders with added oleoresin. Acta Univ. Sapientiae, Alimentaria 9: 50-59. DOI: 10.1515/ ausal-2016-0005

Horváth, Zs.H. dan Hodúr, C. 2007. Colour of paprika powders with different moisture content. Int. Agrophysics, 21: 67-72.

Hunter Associates Laboratory, MSEZ User's Manual 
Kortei, N.K., Odamtten, G.T., Obodai, M., Appiah, V., Akonor, P.T. 2015. Determination of color parameters of gamma irradiated fresh and dried mushrooms during storage. Croatian Journal of Food Technology, Biotechnology and Nutrition 10 (1-2): 66-71.

Kurniawan, H., Bintoro, N., Karyadi, J.N.W. 2018. Pendugaan Umur Simpan Gula Semut dalam Kemasan Dengan Pendekatan Arrhenius. Jurnal Ilmiah Rekayasa Pertanian dan Biosistem6 (1): 93 - 99.

Maskan, A., Kaya, S., \& Maskan, M. (2002). Effect of Concentration and Drying Processes on Color Change Of Grape Juice And Leather (Pestil). Journal of Food Engineering, 54: 75-80.

Maskan, M. 2001. Kinetics of colour change of kiwifruits during hot air and microwave drying. Journal of Food Engineering 48: 169-175

Muchaymien, Y., Rangga, A., \& Nuraini, F. (2014). Penyusunan Draft Standard Operating Procedure (SOP) Pembuatan Gula Merah Kelapa (Studi Kasus Di Pengrajin Gula Merah Kelapa Desa Purworejo Kec. Negeri Katon Kab. Pesawaran). Jurnal Teknologi Industri dan Hasil Pertanian 19 (2): 205 217

Mustaufik dan Haryanti, P. 2006. Evaluasi Mutu Gula Kelapa Kristal Beriodium Yang Dibuat Dengan Teknik Fortifikasi dan Jenis Bahan Baku Yang Berbeda. Jurusan Teknologi Pertanian. Unsoed. Jawa Tengah

Ho, C. W., W. M. Wan, A., M. Y, M., \& Osman, H. 2008. Effect Of Thermal Processing of Palm Sap. In Pakistan Journal of Biological Science 11(7): 989-995.
Nilasari, O. W., Susanto, W. H., \& Maligan, J. M. 2017. Pengaruh suhu dan lama pemasakan terhadap karakterstik lempok labu kuning (waluh). Jurnal Pangan Dan Agroindustri 5(3): 15-26.

Özkan, M., Kirca, A., Chameroglu, B. 2003. Effect of moisture content on CIE color values in dried apricots. European Food Research and Technology, 216(3), 217-219. doi.org/10.1007/s00217-002-0627-6

Pathare, P. B., Opara, U. L., Al-Said, F. A. 2013. Colour Measurement and Analysis in Fresh and Processed Foods: A Review. Food Bioprocess Technol 6:36-60. DOI 10.1007/s11947-012-0867-9

Pontoh, J. 2013. Penentuan Kandungan Sukrosa Pada Gula Aren Dengan Metode Enzimatik. Chem. Prog. 6(1), 26-33

Rao, P.V.K.J., Das, M., Das, S.K. 2009. Changes in physical and thermophysical properties of sugarcane, palmyra-palm and date-palm juices at different concentration of sugar. J Food Eng. 90(4):559-566. doi.org/ 10.1016/j.jfoodeng.2008.07.024

Sahin, S dan Sumnu, S.G. 2006. Physical Properties of Foods. Springer Science+Business Media, LLC. United States of America.

Salehi, F. dan Kashaninejad, M. 2018. Modeling of moisture loss kinetics and color changes in the surface of lemon slice during the combined infrared-vacuum drying. Information Processing in Agriculture 5:516-523. doi.org/10.1016/ j.inpa.2018.05.006

Saricoban, C. dan Yilmaz, M. T. 2010. Modelling the Effects of Processing Factors on the Changes in Colour Parameters of Cooked Meatballs Using Response Surface Methodology. World Applied Sciences Journal 9 (1): 14-22. 
Victor, I., Orsat, V. 2018. Colour changes during the processing of Arenga pinnata (palm) sap into sugar. J Food Sci Technol 55: 3845-3849. doi.org/10.1007/s13197018-3314-8
Wibowo, S., Vervoort, L., Tomic, J., Santiago, J.S., Lemmens, L., Panozzo, A., Grauwet, T., Hendrickx, M., Loey, A.V. 2015. Colour and carotenoid changes of pasteurised orange juice during storage. Food Chemistry 171 :330-340.

doi:10.1016/ 